\title{
PLANT ELICITATION WITH SALICYLIC ACID INCREASES BIOACTIVE COMPOUNDS CONTENT AND ANTIOXIDANT ACTIVITY IN THE INFUSION OF Achillea millefolium L.
}

\author{
ELICITAÇÃO DE PLANTAS DE Achillea millefolium L. COM ÁCIDO SALICÍLICO \\ AUMENTA O TEOR DE COMPOSTOS ATIVOS E A ATIVIDADE ANTIOXIDANTE \\ DA INFUSÃO
}

\begin{abstract}
Pedro Henrique GORNI ${ }^{1}$; Ana Cláudia PACHECO ${ }^{2}$; Jonathan Fogaça Albuquerque SILVA ${ }^{3}$; Ronaldo Rossetti MORELI ${ }^{4}$; Kamille Daleck SPERA ${ }^{5}$; Regildo Márcio Gonçalves SILVA ${ }^{6}$

1. PhD in Agronomy; 2. PhD in Plant Physiology and Biochemistry; 3 and 4 Agronomy engineer filiation at Universidade do Oeste Paulista (UNOESTE), Rodovia Raposo Tavares, km 572, 19067-175, Presidente Prudente, São Paulo, Brazil; 5. PhD student in the Postgraduate Program in Biotechnology. São Paulo State University (UNESP), Institute of Chemistry, Araraquara, São Paulo, Brazil; 6. $\mathrm{PhD}$ in Genetics and Biochemistry. São Paulo State University (UNESP), School of Sciences, Humanities and Languages, Assis, Department of Biotechnology, Laboratory of Herbal Medicine and Natural Products, Assis, São Paulo, Brazil. pgorni@gmail.com
\end{abstract}

\begin{abstract}
This study evaluated the total polyphenols content and the antioxidant activity of the infusion prepared with leaves from Achillea millefolium L. plants treated with salicylic acid (SA). Field cultivated plants received SA foliar applications (T1: control; T2: $1.0 \mathrm{mmol} \mathrm{L}^{-1}$ applications at 20,60 and 100 days after planting - DAP and T3: $1.0 \mathrm{mmol} \mathrm{L}^{-1}$ applications at $100 \mathrm{DAP}$ during three days). The infusions from SA treated plants showed higher levels of total polyphenols and flavonoids compared to the control one. T2 and T3 infusions showed increases in the antioxidant activity by 2,2-diphenyl-1-picrylhydrazyl (DPPH), nitric oxide (NO) and ferric-reducing antioxidant power (FRAP) tests. However, only T2 treated plants had higher antioxidant activity by inhibition of lipid peroxidation (TBARS). It was concluded that elicitation of $A$. millefolium plants with SA can be considered an adequate strategy to increase the production of bioactive compounds and the antioxidant capacity of infusions.
\end{abstract}

KEYWORDS: Phenolic compounds. Nitric oxide. DPPH. FRAP. TBARS.

\section{INTRODUCTION}

Achillea millefolium L. - Asteraceae - is a plant used in traditional medicine for the treatment of gastrointestinal and hepatobiliary disorders and externally in case of skin inflammations and wound healing. In addition, this species is an appetiteinducing drug because of its bitter taste (BENEDEK; KOPP, 2007). Popularly known as yarrow, A. millefolium L. is commercially produced as raw material for the beverage (tea composition) and phytomedicines industries (WILLUHN, 2002). The aerial parts of yarrow plants are used in the form of aqueous or alcoholic extracts, due to the high solubility of their polar phenolic substances (BENEDEK; KOPP, 2007).

The profile of phenolic compounds presents in the tea, extracted during the infusion process, causes this beverage to present high antioxidant activity. In recent years, increasing attention has been devoted to the role of diet in human health, where the ingestion of plant foods rich in antioxidant compounds (fruits, vegetables and herbs) is essential for resistance to cellular oxidative stress, which causes degenerative diseases and aging (SARKAR; SHETTY, 2014).

Elicitor application can be used to increase metabolite production in the plant and to enhance its qualitative value for fresh produce, enriched food, or as a raw ingredient for feed/food and pharmaceutical products (POULEV et al., 2003). The elicitation technique is one of the strategies employed in the cultivation of medicinal plants to increase the content of bioactive compounds (PÉREZ et al., 2014). Elicitors are defined as natural or synthetic substances that, when applied to plants in small concentrations, initiate or increase the synthesis of specific bioactive compounds (NAMLI et al., 2014). Salicylic acid (SA) is a phenolic compound of hormonal nature present in plants, also classified as an elicitor (ANGELOVA et al., 2006). The eliciting action of SA has been proven both by its application in intact plants (PÉREZ et al., 2014; GORNI et al., 2017) and in cell and tissue culture. SA induces the expression of plant genes involved in secondary metabolites production like phenolic compounds, flavonoids, glucosinolates, anthocyanins, carotenoids and 
others. Plant-related factors such as species, cultivar and physiological status influence SA elicitation responses, as well as SA doses and forms of application (GORNI; PACHECO, 2016).

Studies have shown that teas antioxidant activity is higher than popularly fresh consumed vegetables, such as spinach and onion. Such studies demonstrate the importance of tea as a potentially functional food for health (KARORI et al., 2007). The potential antioxidant activity of ethanolic and aqueous extracts of leaves, flowers and seeds of $A$. millefolium was tested by elimination of ferric thiocyanate and $\mathrm{H}_{2} \mathrm{O}_{2}$ radicals. All the extracts showed a high antioxidant activity (KESER et al., 2013).

This study evaluated the effect of foliar application of salicylic acid in yarrow plants on total polyphenol and flavonoid contents and the antioxidant capacity of the resulting infusions.

\section{MATERIAL AND METHODS}

The research was carried out from May to September 2016 under field conditions in Presidente Prudente $\left(22^{\circ} 07^{\prime} 04^{\prime \prime}\right.$ S, 51 ${ }^{\circ} 27^{\prime} 05^{\prime \prime} \mathrm{W}, 471$ ma.s.1.), São Paulo, Brazil. According to Köppen, the climate of the region is characterized as Mesothermal AW, with hot summers and dry winters. The soil is classified as Dystrophic Red Argisol with 10-12\% of clay in the $0-20 \mathrm{~cm}$ layer (EMBRAPA, 2006).

The soil of the experimental area was analyzed according to Raij et al. (2001) The soil of the experimental area was analyzed and corrected by applying limestone for elevate soil base saturation to $80 \%$ according to Boletim 100 (perennial herbaceous species). The organic fertilization was based on tanned bovine manure (10 $\mathrm{kg}$ of manure per square meter of plot, which is higher than the recommended due to the sandy soil).

The seedlings were obtained by vegetative propagation from A. millefolium parent plants, whose exsiccates are deposited in the herbarium of the Federal University of Uberlândia-MG (HUFU 74428). After a period of thirty days, seedlings were transplanted to the field. The adopted spacing was 70 x $50 \mathrm{~cm}$ (NETTO; RAFFAELLI, 2004). Plants were manually irrigated twice a day during the experimental period.

The SA were applied in the leaves by $\mathrm{CO}_{2}$ pressurized sprayer (40 PSI) $(50 \mathrm{~mL}$ per plant) as follows: T1 - control (plants sprayed only with water); T2 - $1.0 \mathrm{mmol} \mathrm{L}^{-1} \mathrm{SA}$ applications at 20,60 and 100 days after planting (DAP) and T3 - 1.0 mmol $\mathrm{L}^{-1} \mathrm{SA}$ applications only at 100 DAP, spraying the plants for three consecutive days. The experimental design was in randomized blocks, with 5 plots $\left(10.5 \mathrm{~m}^{2}\right)$ per treatment in a total of 300 plants (20 plant per plot). The harvest was carried out at 120 days after planting. The 6 central plants of each plot (useful area) were collected.

\section{Preparation of the infusion of Achillea millefolium $L$.}

The harvested leaves were dried in an air drier at $40^{\circ} \mathrm{C}$ for 48 hours. After drying, the leaves went grind. The infusion was obtained by the addition of $100 \mathrm{~mL}$ of distilled water $\left(98^{\circ} \mathrm{C}\right)$ infused with $1 \mathrm{~g}$ of dry leaves of $A$. millefolium. The infusion was maintained at room temperature for 10 minutes under agitation (SU et al., 2006). After this period, infusions were filtered and stored in amber glass bottles and kept under refrigeration $\left(4^{\circ} \mathrm{C}\right)$.

\section{Total polyphenols content $(\mu \mathrm{g} / \mathrm{mL})$}

The total polyphenols content in the different infusion of $A$. millefolium was assessed using Folin-Ciocalteu reagent and gallic acid as a standard (STAGOS et al., 2012). $25 \mu \mathrm{L}$ of each infusion was added to $1.25 \mathrm{~mL}$ of distilled water, $125 \mu \mathrm{L}$ of Folin-Ciocalteu reagent. The homogenized tubes were resting for $3 \mathrm{~min}$ and then $350 \mu \mathrm{L}$ of $25 \%$ sodium carbonate $\left(\mathrm{Na}_{2} \mathrm{CO}_{3}\right)$ and 750 $\mu \mathrm{L}$ of distilled water and then tubes were incubated for $1 \mathrm{~h}$. After that, their absorbance was recorded at $765 \mathrm{~nm}$. The total polyphenols contents of the infusion were reported based on micrograms of gallic acid equivalents per milliliters ( $\mu \mathrm{g} \mathrm{GAE} / \mathrm{mL}$ ). Gallic acid solutions were prepared with concentrations of 25 to $500 \mu \mathrm{g} \mathrm{mL} L^{-1}$ in absolute ethyl alcohol.

\section{Total flavonoid content $(\mu \mathrm{g} / \mathrm{mL})$}

The dosage of flavonoids was performed according to Yao et al. (2013). To quantify the total flavonoid content in A. millefolium infusion, a 100 $\mu \mathrm{L}$ aliquot of the extract was added to the test tube together with $400 \mu \mathrm{L}$ of $70 \%$ alcohol and $50 \mu \mathrm{L}$ of $5 \% \mathrm{NaNO}_{2}$. After 6 minutes $50 \mu \mathrm{L}$ of the $10 \%$ aluminium chloride $\left(\mathrm{AlCl}_{3}\right)$ solution, $300 \mu \mathrm{L}$ of $\mathrm{NaOH}(1 \mathrm{M})$ and $100 \mu \mathrm{L}$ of distilled water were added. The spectrophotometer was read at $510 \mathrm{~nm}$. The total flavonoids contents of the infusion were reported based on micrograms of rutin equivalents per milliliters $(\mu \mathrm{g} \mathrm{RE} / \mathrm{mL})$. Rutin solutions were prepared with concentrations of 25 to $500 \mu \mathrm{g} \mathrm{mL}$ in absolute ethyl alcohol.

\section{Antioxidant activity \\ Free radical scavenger activity DPPH (2,2-diphenyl-1-picryl-hydrazyl)}


In this method, DPPH solution $(500 \mu \mathrm{M})$ was prepared in ethanol, $250 \mu \mathrm{L}$ of this solution was added to $50 \mu \mathrm{L}$ of sample solution (at concentrations of 250,500 and $1000 \mu \mathrm{g} / \mathrm{mL}), 1 \mathrm{~mL}$ of acetate buffer $\left(100 \mathrm{mmol} \mathrm{L}^{-1} / \mathrm{pH} 5.5\right)$ and $1.25 \mathrm{~mL}$ of absolute ethanol and then incubated at room temperature for $30 \mathrm{~min}$, the absorbance was measured at $518 \mathrm{~nm}$ (BLOIS, 1958). The percentage of radical scavenging activity was calculated from Equation: AA $(\%)=\left[\left(A_{c}-A_{s}\right) / A_{c}\right] \times 100$ where $A_{c}$ is the absorbance of the control, and $A_{s}$ is the absorbance of the sample and expressed as $\mathrm{IC}_{50}$ value.

\section{Iron Reduction Activity (FRAP)}

The total antioxidant potential of the tea samples was determined using a modification of the ferric reducing ability of plasma (FRAP) assay of Kukić et al. (2008). $90 \mu \mathrm{L}$ of each sample was added to $2.7 \mathrm{~mL}$ of FRAP reagent $(0.3 \mathrm{M}$ sodium acetate buffer $\mathrm{pH}$ 3.6, tripyridyl triazine (TPTZ) 10 mmol L $\mathrm{L}^{-1}$ and ferric chloride $20 \mathrm{mmol} \mathrm{L}^{-1}$ ) and 270 $\mu \mathrm{L}$ of distilled water. The mixture was vortexed and incubated at $37^{\circ} \mathrm{C}$ for 30 minutes. Absorbance of the solutions was read at $595 \mathrm{~nm}$. The calibration curve was obtained with ferrous sulfate $(100-2000 \mu \mathrm{M})$ and the results expressed in $\mu \mathrm{mol} \mathrm{Fe} \mathrm{Fg}^{2+}$ sample.

\section{Nitric Oxide (NO) sequestering activity}

For the evaluation of nitric oxide (NO) scavenging assay was carried by using sodium nitroprusside, it was used the methodology described by Marcocci et al. (1994) was measured with the Griess reagent. $320 \mu \mathrm{L}$ of each sample was added to $360 \mu \mathrm{L}$ sodium nitroprusside $\left(25 \mathrm{mmol} \mathrm{L}^{-1}\right.$ / phosphate buffer saline $\mathrm{pH} 7.4$ ) and $215 \mu \mathrm{L}$ of Griess reagent was added in test tubes and incubated in a $37^{\circ} \mathrm{C}$ water bath for 2 hours, in the absence of light. The absorbance of the test was determined in a spectrophotometer at $540 \mathrm{~nm}$. The calibration curve was obtained with sodium nitrite $(2.5-80 \mu \mathrm{M})$ and the results expressed in the amount of nitrite formed $\left(\mu \mathrm{M} \mathrm{mL}^{-1}\right)$.

\section{Inhibition of lipid peroxidation (TBARS)}

The evaluation of antioxidant capacity by the inhibition of lipid peroxidation was based on TBARS (Tiobarbituric Acid Reactive Species) methodology, described by Guimarães et al. (2010) with some modifications. Egg homogenate $(1 \mathrm{~mL})$ of $1 \%, \mathrm{v} / \mathrm{v}$ in phosphate buffered saline $\left(20 \mathrm{mmol} \mathrm{L}^{-}\right.$ $1 / \mathrm{pH} 7.4$ ) and $100 \mu \mathrm{L}$ of sample were added to 100 $\mu \mathrm{L}$ of the 2,2'-Azobis(2-amidinopropane) dihydrochloride (AAPH) $(0.12 \mathrm{M})$ to induce lipid peroxidation. The mixture was incubated for 30 minutes at $37^{\circ} \mathrm{C}$. After incubating and cooling at room temperature, it was added $500 \mu \mathrm{L}$ of trichloroacetic acid (15\%) and $500 \mu \mathrm{L}$ of thiobarbituric acid $(0.67 \%)$. The mixture was incubated at $97^{\circ} \mathrm{C}$ for 15 minutes. After incubation, centrifugation $1200 \mathrm{rpm}$ for 10 minutes. Then, the reading of the supernatant was performed at 532 nm. Inhibition (\%) of lipid peroxidation was calculated using the equation: Inhibitory activity $(\%)=\left[\left(A_{c}-A_{s}\right) / A_{c}\right] \times 100$ where $A_{c}$ is the absorbance of the control, and $A_{s}$ is the absorbance of the sample.

\section{Statistical analysis}

All determinations (total polyphenols, flavonoids and antioxidant tests) were repeated five times. Data were tabulated and submitted to analysis of variance $(p \leq 0.05)$, and the Tukey test using the Sisvar software. The results were presented by means of the treatments and standard error.

\section{RESULTS AND DISCUSSION}

The chemical composition of teas and infusions is complex and include polyphenols, alkaloids (caffeine, theophylline and theobromine), amino acids, carbohydrates, proteins, chlorophylls, volatile compounds, minerals, trace elements and other unidentified compounds (KARORI et al., 2007). Among these, polyphenols are the most interesting group and are the main bioactive molecules in teas and infusions, corresponding to about 250-350 $\mathrm{mg}$ of the soluble solids present in this beverage (CABRERA; GIMENEZ; LOPEZ, 2003). Several studies have demonstrated that the teas biological activity is related to the phenolic composition of the plant species that are used for the preparation of infusions (GRAMZA; KORCZAK, 2005). Among these biological activities, is cited the ability of teas act as antioxidants in the human body.

It can be verified that there was variation in the content of total polyphenols and flavonoids in the infusion of yarrow as a function of SA application to the plants (Table 1). Infusions from treated plants showed increases of $43.3 \%$ (T2 treatment) and $54.2 \%$ (T3 treatment) in polyphenols, compared to the infusion obtained from the control plants. According to Ghasemzadeh and Jaafar (2012), when applied exogenously to plants at low concentrations, the SA interacts with stresssignaling mechanisms and induces the synthesis of phenolic compounds. The elicitor signal transduction starts on the surface of the plasma membrane and includes events like the production of reactive oxygen species (ROS) and reactive nitrogen species (RNS), changes in the potential of plasma membrane cell and enhanced ion fluxes $\left(\mathrm{Cl}^{-}\right.$ and $\mathrm{K}^{+}$efflux and $\mathrm{Ca}^{2+}$ influx), rapid changes in 
protein phosphorylation, lipid oxidation, salicylic acid and jasmonic acid accumulation and the de novo biosynthesis of transcription factors, which directly regulate the expression of genes involved in several bioactive compounds (FERRARI, 2010 ; FRANKFATER et al., 2009).

The treatments with SA resulted in significant increases of $27.5 \%$ (T2 treatment) and $45.4 \%$ (T3 treatment) in the total flavonoid contents present in the infusions, when compared to the control (Table 1). This result agrees with Pérez et al. (2014), where SA treatments increased the flavonoids rutin and naringin in peppermint infusion (Mentha piperita).
The presence of phenolic compounds in $A$. millefolium has been associated with its healthpromoting properties, such as choleretic activities, antioxidant, anti-inflammatory and antimutagenicity (GEORGIEVA et al., 2015; HUO et al., 2013). The phenolic compounds present in A. millefolium are flavonoids and phenolic acids. The flavonoids mainly occur as apigenin, luteolin and quercetin. Regarding the phenolic acids, the ubiquituous plant compound chlorogenic acid is accompanied by dicaffeoylquinic acids (DCQAs), namely 1,5-, 3,4-, 3,5- and 4,5-DCQA (BENEDEK; KOOP, 2007).

Table 1. Total compounds in the tea of Achillea millefolium L. plants treated with salicylic acid. Different letters indicate significant difference by the Tukey test $* *(p \leq 0.01)$.

\begin{tabular}{ccc}
\hline Salicylic acid & \multicolumn{2}{c}{ Total compounds $(\mu \mathrm{g} / \mathrm{mL})$} \\
\cline { 2 - 3 } application & Polyphenols & Flavonoids \\
\hline Control & $69.25 \pm 0.00 \mathrm{~b}$ & $239.42 \pm 6.01 \mathrm{c}$ \\
20,60 and 100 DAP & $99.25 \pm 1.44 \mathrm{a}$ & $305.25 \pm 4.33 \mathrm{~b}$ \\
100 DAP & $106.75 \pm 6.03 \mathrm{a}^{* *}$ & $348.175 \pm 3.25 \mathrm{a}^{* *}$ \\
\hline
\end{tabular}

Due to the different types of free radicals and their different forms of action in living organisms (ALVES et al., 2010), it is necessary to use other complementary methods to evaluate the antioxidant activity of plants. The antioxidant substances can present different protective properties and act in several stages of the oxidative process through different mechanisms (SILVA et al., 2010). DPPH is the most commonly used standard method in the world for this purpose. However, DPPH is a synthetic radical, not present in living beings. In this way, other methods like FRAP (based on the antioxidant activity via ferric reducer and iron ion chelation capacity), TBARS (based on antioxidant activity via enzymatic action to reduce lipid peroxidation) and NO - nitric oxide (based on activity antioxidant via free radical sequestration action) are used for antioxidant activity determination. Georgieva et al. (2015) studied the antioxidant activity in $A$. millefolium (leaves and stems) in different tests, observing a greater activity of elimination of free radicals in the DPPH and FRAP tests.

Infusions of A. millefolium plants treated with SA showed high antioxidant activity, both in terms of inhibition of oxidation and elimination of free radicals (Table 2).

Table 2. Antioxidant activity in tea of Achillea millefolium L. plants treated with salicylic acid. Different letters indicate significant difference by the Tukey test $* *(p \leq 0.01)$.

\begin{tabular}{ccc}
\hline Salicylic acid & \multicolumn{2}{c}{ Antioxidant activity } \\
\cline { 2 - 3 } application & $\mathrm{DPPH}\left(\mathrm{IC}_{50}\right)$ & $\mathrm{FRAP}\left(\mu \mathrm{mol} \mathrm{Fe}{ }^{2+} / \mathrm{mg}\right)$ \\
\hline Control & $1283,652 \pm 14,849 \mathrm{c}$ & $0.396 \pm 0.0001 \mathrm{c}$ \\
20,60 and 100 DAP & $1037,098 \pm 7,805 \mathrm{~b}$ & $0.507 \pm 0.0001 \mathrm{~b}$ \\
100 DAP & $936,729 \pm 14,565 \mathrm{a}^{* *}$ & $0.517 \pm 0.0001 \mathrm{a}^{* *}$ \\
\hline & TBARS $(\%)$ & $\mathrm{NO}(\mu \mathrm{M} \mathrm{nitrite} / \mathrm{mL})$ \\
Control & $61.38 \pm 0.038 \mathrm{~b}$ & $10.778 \pm 0.161 \mathrm{c}$ \\
20,60 and 100 DAP & $69.31 \pm 0.028 \mathrm{a}^{* *}$ & $13.222 \pm 0.184 \mathrm{~b}$ \\
100 DAP & $53.60 \pm 0.018 \mathrm{c}$ & $13.863 \pm 0.024 \mathrm{a}^{* *}$ \\
\hline
\end{tabular}


Using the DPPH method, there was a reduction in the $\mathrm{IC}_{50}$ value of $37 \%$ in $\mathrm{T} 3$ treatment when compared to control plants infusion. This increase in antioxidant activity as a result of SA plant elicitation was also verified when the FRAP (28 and $30.5 \%$ for $\mathrm{T} 2$ and $\mathrm{T} 3$ treatments, respectively) and NO (22.7 and $28.6 \%$ for $\mathrm{T} 2$ and T3 treatments, respectively) tests were used. Regarding the TBARS method, there was a $13 \%$ increase in antioxidant activity only in the infusion of the plants from T2 treatment, compared to the control infusion.

The phenolic compounds have, in their structure, several characteristic benzene groups, having as substituents hydroxyl groups (HERNÁNDEZ; PRIETO GONZÁLES, 1999). The hydrogen atoms of the adjacent hydroxyl groups (ortho-diphenols), located at various positions of rings $\mathrm{A}, \mathrm{B}$ and $\mathrm{C}$, the double bonds of the benzene rings and the double bonding of the oxo function ($\mathrm{C}=\mathrm{O}$ ) of some flavonoid molecules guarantee to these compounds their high antioxidant activity (RICE-EVANS; MILLER; PAGANGA, 1996).
There is a high correlation between vegetal species antioxidant effects and total phenolic contents (PIZZALE et al., 2002; PÉREZ et al., 2014). In this way, SA elicitation is a tool for improving the antioxidant activity of herbal and spices, due to improvements in phenolic compounds accumulations.

\section{CONCLUSION}

The results obtained in this study showed that the foliar application of salicylic acid in Achillea millefolium L. plants resulted in increases in total polyphenols and flavonoids present in the infusion, with a consequent increase in their antioxidant activity.

\section{ACKNOWLEDGEMENTS}

This study was financed in part by the Coordenação de Aperfeiçoamento de Pessoal de Nível Superior - Brasil (CAPES) - Finance Code 001 .

RESUMO: Este estudo avaliou o teor total de polifenóis e a atividade antioxidante da infusão preparada com folhas de plantas de Achillea millefolium L. tratadas com ácido salicílico (AS). As plantas cultivadas em campo receberam aplicações foliares de AS (T1 - controle; T2 - aplicação de 1,0 mmol L ${ }^{-1}$ aos 20, 60 e 100 dias após o plantio (DAP) e T3 - aplicações de $1,0 \mathrm{mmol} \mathrm{L}^{-1}$ aos 100 DAP durante três dias consecutivos). As infusões de plantas tratadas com AS apresentaram níveis mais elevados de polifenóis totais e flavonóides em comparação ao controle. As infusões T2 e T3 mostraram aumentos na atividade antioxidante por meio de testes de 2,2- diphenyl-1-picrylhydrazyl (DPPH), óxido nítrico (NO) e poder antioxidante de redução férrica (FRAP). No entanto, apenas plantas do tratamento T2 apresentaram maior atividade antioxidante por inibição da peroxidação lipídica (TBARS). Concluiu-se que a elicitação de plantas de $A$. millefolium com AS pode ser considerada uma estratégia adequada para aumentar a produção de compostos bioativos e a capacidade antioxidante das infusões.

PALAVRAS-CHAVE: Compostos fenólicos. Óxido nítrico. DPPH. FRAP. TBARS.

\section{REFERENCES}

ALVES, C. Q. et al. Métodos para determinação de atividade antioxidante in vitro em substratos orgânicos. Quim Nova, São Paulo, v. 33, p. 2202-2210, oct. 2010. https://doi.org/10.1590/S010040422010001000033

ANGELOVA, Z.; GEORGIEV, S.; ROOS, W. Elicitation of plants. Biotechnol Biotechnol Equip, England, v. 20, p. 72-83, apr. 2006. https://doi.org/10.1080/13102818.2006.10817345

BENEDEK, B.; KOPP, B. Achillea millefolium L. revisited: recent findings confirm the traditional use. Wien Med Wochenschr, Wien, v. 157, n. 13-14, p. 312-314, may. 2007. 
BENEDEK, B.; KOPP, B.; MELZIG, M. F. Achillea millefolium L. s.1. - Is the anti-inflammatory activity mediated by protease inhibition? J Ethnopharmacol, Limerick, v. 113, p. 312-317, jun. 2007.

https://doi.org/10.1016/j.jep.2007.06.014

BLOIS, M. S. Antioxidant determinations by the use of a stable free radical, Nature, London, v. 181, n. 4617 , p. 1199-1200, apr. 1958. https://doi.org/10.1038/1811199a0

CABRERA, C.; GIMENEZ, R.; LOPEZ, C. M. Determination of Tea Components with Antioxidant Activity. J Agric Food Chem, Washington, v.51, n. 15, p. 4427-4435, jun. 2003. https://doi.org/10.1021/jf0300801

EMBRAPA. Sistema brasileiro de classificação do solo. Centro Nacional de Pesquisa de Solos: Rio de Janeiro, 2006, 412p.

FERRARI, S. Biological elicitors of plant secondary metabolites: Mode of action and use in the production of nutraceutics. In: GIARDI M. T., REA G., BERRA B. (eds) Bio-Farms for Nutraceuticals. Advances in Experimental Medicine and Biology, vol 698. Springer, Boston, MA, 2010, p. 152-166.

https://doi.org/10.1007/978-1-4419-7347-4_12

FRANKFATER, C. R.; DOWD, M. K.; TRIPLETT, B. A. Effect of elicitors on the production of gossypol and methylated gossypol in cotton hairy roots. Plant Cell Tiss Organ Cult, Netherlands, v. 98, p. 341-349, sep. 2009. https://doi.org/10.1007/s11240-009-9568-0

GEORGIEVA, L. et al. Achillea millefolium L. -phytochemical profile and in vitro antioxidant activity. Int Food Res J, Malaysia, v. 22, n. 4, p. 1347-1352, dec. 2015.

GHASEMZADEH, A.; JAAFAR, H. Z. Effect of salicylic acid application on biochemical changes in ginger (Zingiber officinale Roscoe). J Med Plants Res, Kenya, v. 6, n. 5, p. 790-795, feb. 2012. https://doi.org/10.5897/JMPR11.1459

GORNI, P. H.; PACHECO, A. C. Growth promotion and elicitor activity of salicylic acid in Achillea millefolium L. Afr J Biotechnol, Kenya, v. 15, n. 16, p. 657-665, apr. 2016.

GORNI, P. H. et al. Increased biomass and salicylic acid elicitor activity in fennel (Foeniculum vulgare Miller). Braz J Food Technol, Campinas, 20e2016172, may. 2017.

GRAMZA, A.; KORCZAK, J. Tea constituents (Camellia sinensis L.) as antioxidants in lipid systems. Trends Food Sci Technol, Cambridge, v. 16, n. 8, p. 351-358, aug. 2005. https://doi.org/10.1016/j.tifs.2005.02.004

GUIMARÃES, R. et al. Targeting excessive free radicals with peels and juices of citrus fruits: grapefruit, lemon, lime and orange. Food Chem Toxicol, Oxford, v. 48, n. 1, p. 99-106, sept. 2010. https://doi.org/10.1016/j.fct.2009.09.022

HERNÁNDEZ, A. M.; PRIETO GONZÁLES, E. A. Plantas que contienen polifenoles. Rev Cubana Invest Biomed, Habana, v.18, n.1, p. 12-14, oct. 1999.

HUO, C. H. et al. Cytotoxic flavonoids from the flowers of Achillea millefolium. Chem Nat Compd, New York, v. 48, n. 6, p. 958-962, jan. 2013. https://doi.org/10.1007/s10600-013-0438-y

KARORI, S. M. et al. Antioxidant capacity of different types of tea products. Afr J Biotechnol, Kenya, v. 6, n. 19, p. 2287-2296, oct. 2007. https://doi.org/10.5897/AJB2007.000-2358

KESER, S. et al. Antioxidant activity, total phenolic and flavonoid content of water and ethanol extracts from Achillea millefolium L. Turk J Pharm Sci, Turkey, v. 10, n. 3, p. 385-392, nov. 2013. 
KUKIĆ, J. et al. Antioxidant and antimicrobial activity of Cynara cardunculus extracts. Food Chem, Barking, v. 107, n. 2, p. 861-868, mar. 2008. https://doi.org/10.1016/j.foodchem.2007.09.005

MARCOCCI, L. et al. The nitric oxide-scavenging properties of Ginkgo biloba extract Egb761. Biochem Biophys Res Commun, New York, v. 201, n. 2, p. 748-55, jun. 1994. https://doi.org/10.1006/bbrc.1994.1764

NAMLI, S. et al. Effects of UV-B radiation on total phenolic, flavonoid and hypericin contents in Hypericum retusum Aucher grown under in vitro conditions. Nat Prod Res, England, v. 28, n. 24, p. 2286-2292, aug. 2014. https://doi.org/10.1080/14786419.2014.940588

NETTO, S. P.; RAFFAELLI, G. Produção experimental de mil folhas (Achillea millefolium L.), visando à extração de óleo essencial. Rev Acad: Ciênc Anim, Curitiba, v. 2, n. 3, p. 27-31, sept. 2004.

PÉREZ, M. G. F. et al. Effect of chemical elicitors on peppermint (Mentha piperita) plants and their impact on the metabolite profile and antioxidant capacity of resulting infusions. Food Chem, Barking, v. 156, p. 273-278, aug. 2014. https://doi.org/10.1016/j.foodchem.2014.01.101

PIZZALE, L. et al. Antioxidant activity of sage (Salvia officinalis and S. fruticosa) and oregano (Origanum onites and $O$. indercedens) extracts related to their phenolic compound content. J Sci Food Agric, England, v. 82, p. 1645-1651, oct. 2002. https://doi.org/10.1002/jsfa.1240

POULEV, A. et al. Elicitation, a new window into plant chemodiversity and phytochemical drug discovery. J. Med. Chem., United States, v. 46, p. 2542-2547, may. 2003.

RAIJ, B.van et al. Análise química para avaliação da fertilidade de solos tropicais. Campinas, Instituto Agronômico de Campinas, 2001. 285p.

RICE-EVANS, C. A.; MILLER, N. J.; PAGANGA, G. Structure-antioxidant activity relationships of flavonoids and phenolic acids. Free Radical Biol Med, New York, v. 20, n. 7, p. 933-956, feb. 1996. https://doi.org/10.1016/0891-5849(95)02227-9

SARKAR, D.; SHETTY, K. Metabolic stimulation of plant phenolics for food preservation and health. Annu Rev Food Sci Technol, Palo Alto, v. 5, p. 395-413, jan. 2014. https://doi.org/10.1146/annurev-food-030713092418

STAGOS, D. et al. Correlation of total polyphenolic content with antioxidant and antibacterial activity of 24 extracts from Greek domestic Lamiaceae species. Food Chem Toxicol, Oxford, v. 50, n. 11, p. 4115-4124, aug. 2012. https://doi.org/10.1016/j.fct.2012.08.033

SU, X. et al. Effects of soaking conditions on the antioxidant potentials of oolong tea. J Food Compos Anal, San Diego, v. 19, n.4, p.348-353, jun. 2006. https://doi.org/10.1016/j.jfca.2005.02.005

WILLUHN, G. Millefolii herba. In: Wichtl, M. Teedrogen und Phytopharmaka, 4th ed. Stuttgart, 2002, p. $399-403$.

YAO, X. et al. In vivo and in vitro antioxidant activity and $\alpha$-glucosidase, $\alpha$-amylase inhibitory effects of flavonoids from Cichorium glandulosum seeds. Food Chem, Barking, v. 139, n. 1, p. 59-66, jan. 2013. https://doi.org/10.1016/j.foodchem.2012.12.045 